S5 Text. Data key: Variables in "S1_Dataset.csv"

\title{
Primary variables:
}

\begin{tabular}{|c|c|}
\hline Physician & A physician identifier \\
\hline Group & $\begin{array}{l}\text { Response-scale group } \\
\qquad \quad 0 \text { : single-scale } \\
\text { - } 1 \text { : separate-scales }\end{array}$ \\
\hline Scenario_Order & $\begin{array}{ll}\text { - } & 1 \text { = scenario seen first } \\
\text { - } & 2 \text { = scenario seen second }\end{array}$ \\
\hline Scenario & $\begin{array}{l}\text { - } 0: \text { dyspnea } \\
\text { - } 1 \text { : fatigue }\end{array}$ \\
\hline Cue_Order & $\begin{array}{l}\text { Order in which cues were presented } \\
\qquad \begin{array}{l}\text { - } \\
\text { - }\end{array} \text { - } 2 \text { first } \text { = second cue, etc. }\end{array}$ \\
\hline Proleader & $\begin{array}{l}\text { A physician's proleader distortion score for a given cue: } \\
\text { - } \quad \text { single-scale: a physician's distortion of a given cue (identical to } \\
\text { antitrailer) } \\
\text { - } \text { separate-scales: a physician's distortion of a given cue in } \\
\text { relation to the leading diagnosis }\end{array}$ \\
\hline Antitrailer & $\begin{array}{l}\text { A physician's antitrailer distortion score for a given cue: } \\
\text { - } \quad \text { single-scale: a physician's distortion of a given cue (identical to } \\
\text { proleader) } \\
\text { - } \text { separate-scales: a physician's distortion of a given cue in } \\
\text { relation to the trailing diagnosis }\end{array}$ \\
\hline Verb_Lead & $\begin{array}{l}\text { A physician's verbal evaluation of a cue in relation to the leading } \\
\text { diagnosis: } \\
\begin{array}{l}\text { - } 0 \text { : nothing } \\
\text { - } 1 \text { : unclear } \\
\text { - } 2 \text { : supportive } \\
\text { - } 3 \text { : non-supportive }\end{array}\end{array}$ \\
\hline Verb_Trail & $\begin{array}{l}\text { A physician's verbal evaluation of a cue in relation to the trailing } \\
\text { diagnosis: } \\
\text { - } 0 \text { : nothing } \\
\text { - } 1 \text { : unclear }\end{array}$ \\
\hline
\end{tabular}




\begin{tabular}{|c|c|}
\hline & $\begin{array}{l}\text { - 2: supportive } \\
\text { - } 3 \text { : non-supportive }\end{array}$ \\
\hline
\end{tabular}

The remaining variables are derived from "Verb_Lead" and "Verb_Trail":

\begin{tabular}{|c|c|}
\hline Verb_Lead_Nothing & $\begin{array}{l}\text { Indicates whether a physician evaluated a cue in relation to the } \\
\text { leading diagnosis: } \\
\begin{array}{l}\text { - } 0 \text { : nothing } \\
\text { - } 1 \text { : other (unclear, supportive or non-supportive) }\end{array}\end{array}$ \\
\hline Verb_Trail_Nothing & $\begin{array}{l}\text { Indicates whether a physician evaluated a cue in relation to the } \\
\text { trailing diagnosis: } \\
\begin{array}{l}\text { - } 0 \text { : nothing } \\
\text { - } 1 \text { : other (unclear, supportive or non-supportive) }\end{array}\end{array}$ \\
\hline Verb_Lead_Supportive & $\begin{array}{l}\text { Indicates whether a physician's verbal evaluation of a cue in } \\
\text { relation to the leading diagnosis was supportive: } \\
\text { - } 0 \text { : other (nothing, unclear or non-supportive) } \\
\text { - } 1 \text { : supportive }\end{array}$ \\
\hline Verb_Trail_Nonsupportive & $\begin{array}{l}\text { Indicates whether a physician's verbal evaluation of a cue in } \\
\text { relation to the trailing diagnosis was non-supportive: } \\
\text { - } 0 \text { : other (nothing, unclear or supportive) } \\
\text { - } 1 \text { : non-supportive }\end{array}$ \\
\hline
\end{tabular}

